\title{
New Sincerity VS Irony: Analysis of the Existing Cultural and Political Discourses in the Media Space
}

\author{
Alexander Sokolov ${ }^{1, *}$ Polina Shabrova ${ }^{1, a}$ \\ ${ }^{1}$ Department of social and political theories, Yaroslavl State University, Yaroslavl, Russia \\ aEmail: shabrovapolina@gmail.com \\ "Corresponding author. Email: alex8119@mail.ru
}

\begin{abstract}
The paper considers the issue of relatively recently appeared trend called "New Sincerity" and its significance in cultural and political discourses. Tracing the becoming of New Sincerity as a cultural paradigm, it's stated to say that it cannot be excluded from larger cultural debate on the crisis of postmodernism. The authors also show the way how New Sincerity is influencing the changes in the society through integration into both traditional and new media, based on concrete examples. Moreover, they prove that new media foster embedding of New Sincerity in the existing culture. The authors come to conclusion that there are necessary conditions for New Sincerity as a cultural norm to set in and replace, or more likely complement, irony. However, there is still a thin line between New Sincerity and oversharing, and there is a threat of using fake New Sincerity for personal gain. Nevertheless, this issue needs further investigation.
\end{abstract}

Keywords: New Sincerity, cultural discourse, political discourse, media space, traditional media, new media,

irony, postmodernism, post-postmodernism

\section{INTRODUCTION}

Poet Anthony Robinson wrote on his blog back in 2005, "The New Sincerity has built-in irony. There's nothing 'new' about sincerity." [1]. Nevertheless, over the past few years this trend has become widely discussed as a part of "Irony is dead" debate. But still, it has no common definition as well as there is no consensus on its relevance. In this regard, the aim of the research is to reveal New Sincerity's significance in cultural and political discourses. The purposes of the research are: to trace the formation of New Sincerity as a cultural paradigm, to give its definition in accordance with all aspects, and to discover how New Sincerity is modifying the society we live in through television and the Internet as media channels, and its integration into politics. Due to the fact that discussion of New Sincerity requests presence of content that would reliably reflect contemporary tendencies, the majority of the source base of this paper is analysis of the existing research on the topic and discourses in the media space (traditional and new media).

*Fund: The reported study was funded by the grant from the President of the Russian Federation for state support of young Russian scientists MD-855.2020.6 "Mobilization and demobilization in modern practices of protest activity"

\section{HISTORICAL BACKGROUND AND MISINTERPRETATION OF THE TERM "NEW SINCERITY"}

New Sincerity has been around since mid-1980s. Back to those days, understanding of New Sincerity differed according to the country we turn to, e.g. in Russia, it can be traced from Perestroika in USSR and Post-Soviet Russia. Here, we must outline the names of cultural theorist Mikhail Epstein, whose description of New Sincerity proves that it cannot be excluded from a larger debate on changing cultural trends, and poet Dmitry Prigov. Due to deep changes in worldview happening at that times, they used New Sincerity as an antithetical concept to reveal absurdism of Soviet/Russian culture of that epoch, "a gap between the existential understanding of things and their official ideological interpretation" $[2 ; 3]$.

Popularization of New Sincerity dates back to 1990 s and early 2000s and can be considered as a part of discourse on tiredness from postmodernism in cultural studies [4]. Here, we must mention writer David Foster Wallace whose ideas were centered on abandoning the postulates of postmodernism mostly expressed in irony. Wallace concluded that irony serves an exclusively negative function as it deconstructs the existing culture without introducing anything new to it, so its replacement by New Sincerity is of vital importance. 
Unfortunately, irony has become a common subject of discussion only almost two decades after his fundamental works' publications. But still, Wallace makes a huge contribution to studying New Sincerity posthumously.

So, it would be more accurate to say that popularization of New Sincerity during this period was influenced by radio host Jesse Thorn. In 2006, he published "A Manifesto for The New Sincerity", which commemorated Thorn's name as one of the brightest New Sincerity representatives as it contains the most quoted definition of this cultural phenomenon: "Think of it as irony and sincerity combined like Voltron, to form a new movement of astonishing power. Or think of it as the absence of irony and sincerity, where less is (obviously) more" [5]. However, it caused misinterpretation of the term as it can be easily confused with post-irony. Urban Dictionary determines "post-ironic" as a genuine assess of something with a sarcastic tone which can be described as an unintentional response to Generation X's use of sarcasm. It can also be attributed to a situation when ironic appreciation of something becomes sincere because of the enjoyment of its terribleness [6]. Little Big's music video UNO for Eurovision 2020 is a great modern example. Firstly, it is hard to tell whether they truly think Bell-bottom pants are great or they are just being sarcastically nostalgic about 1970s. Secondly, the same thing can be referred to the viewers: do they enjoy the song or foolishness of what is going on?

Another accomplishment and at the same time controversial statement of Jesse Thorn lies in the fact that he outlined that slow painful death of irony and its replacement by sincerity was connected with irony's old age and not with the 9/11 terrorist attacks after which it resurrected for a couple of years [5]. But although there is no absolute consensus on starting point for world's rearrangement, some experts say that it takes its origins from the fall of the Berlin Wall in 1989 and is fueled by subsequent, mostly tragic events including 9/11. Therefore, despite radical statements that postmodernism is over, made at the beginning of the 21st century by Linda Hutcheon [7], we are not completely done with the postmodernism page of our history, so we still cannot say that irony is dead irreversively. It is more like New Sincerity is about to replace the cynic irony of postmodernism and end the formation of a new "Post-9/11" culture; and this process can (and must) be scrutinized at the present moment.

So, wide discussion of New Sincerity takes us to 2010 s and 2020s, making us its witnesses. Big contribution to public discourse on the topic was made by Princeton professor Christy Wampole and her essay "How to Live Without Irony" published in The New York Times in 2012. Wampole assures the reader that the world stepped into the age of Deep Irony and gives a reasonable explanation for this: it happened because of the common perception that Generation $\mathrm{Y}$, or Millennials, cannot offer anything new to the world. Besides, Wampole concludes that living in irony means to hide in public as it allows the person to dodge responsibility for their preferences, which can be mostly referred to hipsters [8].

This work caused severe debates, and Elizabeth Janette Morris in her thesis, taking as a basis Wampole's idea, explains the real connection between hipsters, ubiquitous irony and culture. First of all, the term "hipster" in popular imagination can be referred to anyone who is a little bit off mainstream culture, and such approach negates cultural critiques and makes any true resistance to acknowledged culture less visible and significant. Besides, those who use this term just try to outline the binary opposition "good me"/"bad hipsters", regarding the degree of addiction to irony everyone finds self guilty of, and ignore the fact that labeling certain type of people as "hipsters" likely expresses common tiredness of irony as a cultural norm in postmodernism [9].

Researchers name several concepts that suggest the next stage after postmodernism; post-postmodernism is usually used as an umbrella term which includes several approaches, such as altermodernism, cosmodernism, digimodernism, performatism, post-digital, posthumanism and metamodernism. "There are convergences and divergences between these conceptualizations; they complement each other as much as they compete" [7]. But it is more rational to focus on the last conception, metamodernism, which includes New Sincerity as one of its basic "sensibilities"; in some cases, they are used as synonyms which is not quite right.

The term "metamodernism" was firstly used by Vermeulen and van den Akker in "Notes on Metamodernism" (2010); the prefix meta- is derived from Plato's metaxis and refers to notions "with", "between", and "beyond". Metamodernism appeared as a response to a collective call for change and its main idea is constant oscillation, not balance, between modernism and postmodernism and some opposite phenomena including irony and sincerity. Therefore, "the metamodern generation understands that we can be both ironic and sincere in the same moment; that one does not necessarily diminish the other." $[10 ; 11]$

Summing everything up, New Sincerity could be defined as a cultural paradigm emerged in the second half of the 20th century as a part of discourse on changing cultural trends, mostly introduced as a response to irony as a cultural norm in postmodernism, nevertheless, not diminishing its significance.

More facile definition of New Sincerity could include that it is a recently appeared trend based on the 
ideas of revisioning our attitude to what is happening around towards a more serious approach and erasing the boundaries of what we consider acceptable to share with others, leading to outspokenness.

\section{NEW SINCERITY AS A TOOL TO DESTROY IRONY ON TELEVISION}

Back to the second half of the 20th century, television became one of the driving forces of cultural revolution and a powerful medium for imposing a certain world perception on its viewers; so, television and particularly advertising started to use irony as a shield from such accusations. We can trace this if we refer to David Foster Wallace and his essay "E Unibus Pluram: Television and U.S. Fiction" (1993), "Television was practically made for irony". In fact, television still uses a trick to be immune to condemnation: if you criticize yourself, you make it hard for others to do that; you indicate that you are aware of the issue and deconstruct it with irony, but you do not provide any meaningful solutions of existing problems [12].

To confirm that these statements are relevant nowadays, we should turn to modern TV shows. The usage of cynic irony can be clearly traced in 'Family Guy' (1999-present). The show makes references to pop culture, exaggerated stereotypes and historical events, but it all only demonstrates the knowledge that cultural discourse exists [13]. Again, there is no critical approach, and the usage of irony in it is intended to highlight common awareness that something is wrong. The only thing such method can offer is to cover the issue superficially and at its best advice to fix anything using your hobby or family's support. But it is the same thing as saying "Don't be sad!" to a person in depression. To overcome this problem, showrunners should make a choice towards seriousness and forthrightness which are, in fact, the main tools of New Sincerity.

A whole new approach to highlighting social diseases through entertainment was introduced in Netflix original series "BoJack Horseman" (20142020). An American company "Wisecrack" analyzed the show and described its philosophy as existential nihilism as "BoJack Horseman" tries to answer the question: "If life is meaningless, what can we do about it?" It also makes an attempt to rethink famous philosophers' ideas, e.g. Blaise Pascal's self-distraction, Jean-Paul Sartre's radical freedom, and Albert Camus' absurdism [14]. At first, it may seem impossible that an adult cartoon could tackle serious issues, but it turns outs to be its main advantage. Its creator Raphael BobWaksberg explains, "The brighter and the sillier and the cartoonier we went, the more the audience was willing to go with us to these very melancholy places that maybe on a live-action show would have come off as indulgent or saccharine. And the darker we went, the more our audience was willing to follow us" [15].

The show was really successful in portraying devastating depression, anxiety, addictions that are supposed to help escape from the reality, desire to be perceived as a good person, and many other dark sides of life that are relatable to one or another part of the viewers. What is crucially important and what distinguishes this animated series, is that the main character cannot be described as "a nice guy", he is sarcastic and self-absorbed, but these are not the main traits that determine him. First of all, BoJack cares about people he loves and cares what others think about him. But most importantly, he sincerely believes in redemption despite his regrettable life decisions [16]. No TV show of "age of Deep Irony" can boast about it. But the moral is, everything has consequences and you cannot leave behind all the mistakes of your past and pretend that you are a completely different person even after a rehab. Because BoJack, like most of us, can only continue to be a person with a potential to be worse or better [17]. Portraying this ugly truth in a TV show that is supposed to be entertaining is a whole new level of New Sincerity.

\section{NEW SINCERITY ON SOCIAL MEDIA AS A DRIVING FORCE OF CHANGES IN THE SOCIETY}

However, television has lost its status of the only source of information that can influence the worldview of the entire planet's population. There is no recent statistics on this issue, but in 2019 total Internet consumption was expected to exceed TV consumption [18]. What we are interested in, is that widespread usage of the Internet is undoubtedly changing the ways we produce and consume information.

New media foster integration of New Sincerity into our daily life. Notably, it mostly refers to Millennials and Gen $\mathrm{Z}$ as they perceive the Internet as a powerful tool to shape their community and somehow change the sacralization of aspects of life that were traditionally kept private a few decades ago. So, nowadays it is more socially acceptable to cover various intimate issues on social media from writing a post about problems in your romantic relationship to sharing your own story about facing harassment even despite domination of victim blaming in such discourse.

In 2017, the discussion of harassment reached an international level. "metoo." Movement, which was founded in 2006 by Tarana Burke to help survivors of sexual violence, specifically Black women and girls, was reborn in a new way and went viral as a mass campaign against sexual abuse under a \#MeToo hashtag firstly used by actress Alyssa Milano on Twitter in 2017 [19]. This act of New Sincerity when survivors, dominantly female, all around the globe 
disclosed their stories resulted in rethinking existing cultural norms towards intolerance of sexual abuse, changing legislation in some countries with introduction of new preventive measures and stricter penalties, and finally Harvey Weinstein's sentence to 23 years in prison. It is an example of how New Sincerity, on social media in particular, is reforming the society we live in.

On the contrary, as Brigid Delaney wrote in The Guardian, "David Foster Wallace was right - even in paradise we will need the Internet. There was one thing he didn't predict: that when entertainment and addiction met in the Internet, rage and hate would follow" [20]. A bright example of that is a recent scandal happened with Russian Instagram blogger with 1 million followers Katerina Didenko: her husband poured $25 \mathrm{~kg}$ of dry ice into the pool at her birthday party, which caused him and two other guests to die [21]. Right after the tragedy, Katerina posted several Instagram stories where she was crying explaining what happened; and she still continues to share the details of the situation on her blog: how she turned to a psychotherapist, how she told her children about their father's death, and so forth, which causes a negative reaction from Internet users. Didenko's case is very important due to a number of social questions it rises: about the social construct of proper grieving, about blaming on women actions of other people, but in the context of New Sincerity, she is accused of social media addiction, oversharing, and PR on the tragedy as she uses a beauty filter when talking about her loved one's death. In fact, this case may cause a revision of what we consider "decorous" to share with others, and alterations are already happening.

Again, it does not mean that irony would fully disappear from the Internet space. As it has already been mentioned, we can be sincere and ironic at the same time. At least, a research has found that memes about death, suicide, hopelessness, etc. may have a potential therapeutic effect on people with significant depressive symptoms, e.g. such memes might make light of a negative experience and create a sense of affiliation with others with the same symptoms [22].

\section{NEW SINCERITY AS A PART OF POLITICAL DISCOURSE IN TRADITIONAL AND NEW MEDIA}

It may seem strange to talk about New Sincerity in media covering politics while living in the world where Oxford Dictionaries named "post-truth" Word of the Year in 2016, which was largely influenced by the US Presidential elections and personally Donald Trump [23]. After this information was revealed, politics reporter Amy B Wang wrote, "It's official: Truth is dead. Facts are passe" [24]. But really, it all can become a favorable ground for integrating New Sincerity into both traditional and new media.
Trump sticks to rhetoric which he portrays as "saying out loud what every American secretly thinks of". He openly lies and fabricates facts, but the thing is, at that moment he truly believes in everything that he says [25]. Important to outline: in Trump's case, emphasized straightforwardness is not some kind of a personality trait, it is more like a response to a call of nostalgia in the times of masculinity in crisis and a weapon to attack political correctness [26], which makes Trump's sincerity a cultural construct. This is a paradox which actually has a rational base: Trump is being sincere and utterly dishonest at the same time, but he wins the mercy of the electorate. Moreover, Trump's tactic to charge any objectionable press of spreading fake news and misuse of this term made a contribution to overall disbelief in facts distributed by official news media (in September 2016, a global analytics firm Gallup revealed that American citizens' level of trust to mass media hit an all-time low value in its polling history $-32 \%$ [27]). The main reason why people trust him is his image of a self-made man who knows the ins and outs of the media and business; besides, his policy of using social media as a channel to communicate with the electorate without press as the middleman secured his reputation of an independent person who can say (or tweet) whatever he wants to.

As we can see, no exposing articles and TV stories or even fact-checking in Google era could ruin Trump's independence in the eyes of the voters, which means that media literacy is highly important nowadays, but it is not the cure for the traditional media crisis we find ourselves in because a) perception is the most important thing in politics and b) people have a right to do with the given to them information whatever they wish to. Obviously, we deal with an intersection of post-truth and New Sincerity: there is a strong need for honesty, genuine passion, and expertness to be integrated into public policy, so the masses tend to believe someone who looks and sounds "truthiness" (this term has been coined by Stephen Colbert in 2005).

This leads us to debate on new media and their effect on the way we consume political information. Professor Philip Howard, Director of the Oxford Internet Institute and OxTEC Commissioner, explains, "Technology has allowed more people to participate in political discussion than ever before and has been vital to engaging harder to reach groups. Social media is also now fully embedded in political communication" [28]. So, the masses are not waiting for rescuing truth because what counts as truth varies through space and time [29]; they are craving for political transparency, at least on particular politicians' social media. Of course, Trump can be called the first one who began to use Twitter as "modern day presidential" tool [30], but he is totally not the first politician who uses social media the very right and effective way. 
Congresswoman Alexandria Ocasio-Cortez is considered one of the most influential American politicians on social media; despite the fact that she has 11.3 times less followers on Twitter than US President (data for March 2020), her interaction rate is much higher (2.8\% VS Trump's $0.2 \%$ in 2018 [31]). The main reason of Ocasio-Cortez's popularity is a nonstandard, for a person who was elected to House of Representatives, style of her accounts: she flaunts her real daily routine from showing herself doing laundry to taking her followers on an excursion to Congress using Instagram stories [32]. In fact, she makes politics great again because she gives everyone a chance to get involved by explaining current news through the perspective of what she believes in siting with a bowl of popcorn in her apartment through a livestream video. This transparency makes Alexandria Ocasio-Cortez a huge contributor of integrating New Sincerity into politics and especially public policy.

Nevertheless, in spite of the fact that Ocasio-Cortez seems 'too much sincere', she can be accused of selective gatekeeping. Frankly speaking, she uses the same strategy as Donald Trump, but in a more elegant way, and frequently refuses to talk to the free press to avoid uncomfortable questions [33]. Therefore, she ignores traditional media as the middleman between her and the voters and forms a favorable image of herself through direct interaction with the masses on social media.

So, there is a strong social demand for New Sincerity to be integrated into political sphere, which is mostly shown in expectation of politicians' transparency on the Internet in the era of distrust to the traditional press. However, the question, whether the image of every particular politician on social media is driven by striving for publicity or it is just a wellplanned PR-campaign to gain popularity among the voters, still remains open.

\section{CONCLUSION}

Summing everything up, it is founded to say that New Sincerity as a cultural paradigm is rapidly invading all spheres of the society and is undoubtedly modifying the way we produce and consume information and communicate with the others. This can be traced even in television broadcasting, the natural habitat of irony, and the most conservative sphere of life - politics. Besides, being intruded on both traditional and new media, New Sincerity leads to significant changes in the society we live in from Facebook monitoring depressive posts to check in on its users' mental health to integrating harassment into national dialogues about intolerance of sexism and sexual violence around the globe. However, more work needs to be done due to several facts. For instance, some acts of displaying New Sincerity are still considered oversharing and cause bullying of those who show too much of their private life. Moreover, there is a threat of fake New Sincerity, e.g. in case of need to gain more followers on social media and/or receive social approval.

Of course, prerequisites for integration of New Sincerity into our daily life could be found at the end of the second half of the 20th century, but necessary conditions for its spreading as a new cultural norm instead of or along with irony can be traced only at the turn of 2010s and 2020s. Therefore, New Sincerty cannot be excluded from a larger cultural discourse on crisis of postmodernism and what comes after it Nevertheless, due to the fact that New Sincerity and metamodernism, which includes it as one of its core "sensibilities", are not well-acknowledged yet, this issue needs further investigation.

\section{References}

[1] A few notes from a New Sincerist // Blogger.com URL: http://luckyerror.blogspot.com/2005/07/few-notes-from-newsincerist.html

[2] Ellen Rutten. Sincerity after communism: a cultural history. New Haven: Yale University Press, 2017, pp. 9-10.

[3] NEW SINCERITY // HiSoUR URL: https://www.hisour.com/new-sincerity-34646/

[4] Постпостмодернизм // Издательский дом ПостНаука URL: https://postnauka.ru/video/95729

[5] A Manifesto for The New Sincerity // Maximum Fun URL https://maximumfun.org/news/manifesto-for-new-sincerity/

[6] Urban Dictionary URL https://www.urbandictionary.com/define.php?term=post-ironic

[7] Postmodernism is dead. What comes next? // The Times Literary Supplement (TLS) URL: https://www.thetls.co.uk/articles/postmodernism-dead-comes-next/

[8] How to Live Without Irony // The New York Times URL: https://opinionator.blogs.nytimes.com/2012/11/17/how-to-livewithout-irony/

[9] Elizabeth Janette Morris. Communication Therapy: David Foster Wallace and the New Sincerity in U.S. Fiction. Department of English and Comparative Literature. University of North Carolina-Chapel Hill, 2014, pp. 16-19.

[10] METAMODERNIST // MANIFESTO // metamodernism.org URL: http://www.metamodernism.org/

[11] Metamodernism: A Brief Introduction // Notes on Metamodernism URL: http://www.metamodernism.com/2015/01/12/metamodernisma-brief-introduction/

[12] David Foster Wallace. E unibus pluram: television and U.S. fiction URL: https://www.thefreelibrary.com/E+unibus+pluram\%3A+televisi on+and+U.S.+fiction.-a013952319

[13] David Foster Wallace - The Problem with Irony // YouTube channel Will Schoder URL: https://youtu.be/2doZROwdte4

[14] The Philosophy of BOJACK HORSEMAN // YouTube channel Wisecrack. https://www.youtube.com/watch?v=rORIDYHOFTQ

[15] 'BoJack Horseman' Rides Into The Sunset // NPR URL: https://www.npr.org/2020/02/01/801629428/bojack-horsemanrides-into-the-sunset 
[16] Why Bojack Horseman Will Save Us All // A Medium Corporation URL: https://medium.com/@PeteWWrites/whybojack-horseman-will-save-us-all-457bdee9f8cb

[17] BoJack Horseman Ending, Explained - Then You Keep Living /I YouTube channel The Take URL: https://youtu.be/z9oZKylZeCM

[18] 2019 Marks an Inflection Point in Media Consumption // Statista URL: https://www.statista.com/chart/9761/daily-tv-andinternet-consumption-worldwide/

[19] About - Me Too Movement // metoomvmt.org URL: https://metoomvmt.org/about/\#history

[20] David Foster Wallace was right - even in paradise we will need the internet // The Guardian URL: https://www.theguardian.com/commentisfree/2018/sep/20/david -foster-wallace-was-right-even-in-paradise-we-will-need-theinternet

[21] Екатерина Диденко // Memepedia URL: https://memepedia.ru/ekaterina-didenko/

[22] Exploratory study on the role of emotion regulation in perceived valence, humour, and beneficial use of depressive internet memes in depression // Springer Nature Limited URL: https://www.nature.com/articles/s41598-020-57953-4

[23] Word of the Year 2016 // OxfordLanguages URL: https://languages.oup.com/word-of-the-year/2016/

[24] 'Post-truth' named 2016 word of the year by Oxford Dictionaries /I The Washington Post URL: https://www.washingtonpost.com/news/thefix/wp/2016/11/16/post-truth-named-2016-word-of-the-year-byoxford-dictionaries/

[25] The Seven Broken Guardrails of Democracy // The Atlantic URL: https://www.theatlantic.com/politics/archive/2016/05/theseven-broken-guardrails-of-democracy/484829/

[26] Donald Trump and the Crisis of Masculinity // CounterPunch URL: https://www.counterpunch.org/2016/02/26/donald-trumpand-the-crisis-of-masculinity/

[27] Americans' Trust in Mass Media Sinks to New Low // Gallup URL: https://news.gallup.com/poll/195542/americans-trustmass-media-sinks-new-low.aspx

[28] Collective Action Needed Now to Tackle Spread of Disinformation in Public Life, Finds New Report // Oxford Technology and Elections Commission URL: https://oxtec.oii.ox.ac.uk/collective-action-needed-now-totackle-spread-of-disinformation-in-public-life-finds-new-report/

[29] Post-truth politics and why the antidote isn't simply 'factchecking' and truth // The Conversation URL: https://theconversation.com/post-truth-politics-and-why-theantidote-isnt-simply-fact-checking-and-truth-87364

[30] @ realdonaldtrump on Twitter URL https://twitter.com/realDonaldTrump/status/8812817550173552 64

[31] How Alexandria Ocasio-Cortez beat everyone at Twitter in nine tweets // The Guardian URL: https://www.theguardian.com/usnews/2019/feb/12/alexandria-ocasio-cortez-twitter-social-media

[32] Alexandria Ocasio-Cortez Is Using Instagram Stories To Lift The Veil On Congress And It's Genius // ELLE URL: https://www.elle.com/culture/careerpolitics/a25062833/alexandria-ocasio-cortez-congresswomaninstagram-stories/

[33] How Alexandria Ocasio-Cortez's Obsession-Worthy Instagram Is Changing The Game // Refinery29 URL: https://www.refinery29.com/en-us/2019/04/229351/alexandriaocasio-cortez-instagram-live-social-media-message 